\title{
ASSESMENT OF ANTIDERMATOPHYTE ACTIVITY OF OIL FROM CURCUMA LONGA L. IN VITRO
}

\author{
Nguyen Thi Mai Huong ${ }^{1}$, Pham Viet Cuong ${ }^{2}$, Nguyen Thi Kim Cuc ${ }^{2 *}$ \\ ${ }^{1}$ University of Economic and Technical Industries \\ ${ }^{2}$ Institute of Marine Biochemistry, VAST, *kcnguyenthi@gmail.com
}

\begin{abstract}
Curcuma longa L. is a rhizomatous herbaceous perennial plant, and its essential oil showed antifungal, antibacterial, antioxydant, antivenom, and antitumor effects. The antidermatophytes of oil from turmeric was demonstrated. This study was carried out in order to evaluate inhibition activity of oil from Vietnamese turmeric against two strains dermatophyte, Trychophytol mentargrohytes and Candida albicans. The oil from Vietnamese turmeric was obtained by hydrodistillation method and its chemical composition was determined by GC/MS. By comparing with authentic reference compounds in mass spectra library Nist 98.1 and Wiley 275.L, 13 compounds of oil from Vietnamese turmeric were identified. The received results showed that, the oil is rich in turmerones (about 44\%), which has been recognized as major constituent attributing to antimicrobial activity. By disc diffusion method, the antifungal activity of the turmeric essential oil against $T$. mentargrophyte and $C$. albicans was demonstrated. The MICs of the turmeric oil for $T$. mentargrophytes và $C$. albicans were $0.5 \%$. The minimal killing time for $C$. albicans was 60 minutes and for T. mentargrophyte was 90 minutes after treatment with the turmeric oil.
\end{abstract}

Keywords: Curcuma longa, dermatophytes, inhibition, turmeric oil, turmerones.

\section{INTRODUCTION}

Dermatophytoses is the common forms of fungal infection found in most countries. The diseases are caused by dermatophytes, the molds that require keratin for nutrition and must live on stratum corneum, hair, or nails to survive. The infection can be transmitted from man to man, animal to man and even from soil to man.

Trichophyton mentagrophytes is a pathogenic agent causing tinea cruris, tinea pedis, tinea capitis..., meanwhile Candida albicans causing dermatitis and diseases of nail, corners of nail. Dermatophytose is still a public health problem around the world and imported drugs used for the treatment of this disease are expensive.

Medicinal plants are widely used as an integral part of primary health care in many asian countries and important natural sources of anti-infectious agents. Curcuma longa is a rhizomatous herbaceous perennial plant, of the family Zingiberaceae and widely used as a spice and colouring agent, as well as pharmaceutical properties in traditional medicine $[5,12]$. In Vietnam, genus Curcuma comprises at least 16 species and many of them have been used in ethnical medicines, such as $C$. longa $\mathrm{L}$., C. aeruginosa Roxb., C. zedoaria (Berg.) Rosc., and $C$. pierreana Gagnep. [4]. The biological properties of extracts of Zingiberaceae species have been investigated by many workers and their biological activity were reported including antiemetic, anticancer, antiinflammation, hypolipidemic, antioxidant, antibacterial and antifungal $[1,10]$.

In the last years, research in essential oils of aromatic and medicinal plants has attracted many investigators. Recently, several studies demonstrated potential use of these natural products as antifungal agents, their use in a number of pharmaceutical, food and cosmetic products $[8,16]$. Turmeric essential oil showed antifungal, antibacterial, antioxydant, antivenom, and antitumor effects. The inhibitory effect of turmeric essential oil against microorganisms has been reported by many authors $[1,2,9,10,14]$

Keeping in view the antifungal activity of turmeric oil, the present study was conducted to demonstrate it's inhibition on growth of dermatophyte Trichophyton mentagrophyte and the yeast-like fungi Candida albicans. The 
chemical composition of oil extracted by hydrodistillation was determined by GC-MS.

\section{MATERIALS AND METHODS}

Rhizomes of $C$. longa collected from Hung Yen province were washed, dried and then ground. One kilogram of turmeric powder (about $4 \mathrm{~mm}$ particles) were put into steam distillation unit, add distilled water at ratio 2:1 (v/w), some pumice stone, and the process was carried out on electric cooker for 8 hours. The essential oil was condensed by cooling water at room temperature.

Two strains of fungi were used: Trichophyton mentagrophyte and Candida albicans obtained from Dermatology hospital (Hanoi, Vietnam). The Sabouraud medium was used for all experiments.

Determination of antifungal activity: Inhibition zone diameter was determined by the disc diffusion method as decribed elsewhere [13]. The clear zone surrounding each disc was interpreted as minimum inhibitory concentration (MIC). In order to determine minimum killing time, one milliliter of the medium supplemented with the oil (final concentration was $0.5 \%$ for $C$. albicans and $0.7 \%$ for $T$. mentagrophyte) was prepared and inoculated with $0.1 \mathrm{ml}$ of freshly grown test fungi and incubated at appropriate temperature. After 0, 5, 10, 15, 20, 25, 30, 60, 90, $120 \mathrm{~min}$ intervals, $10 \mu \mathrm{l}$ of the sample from above test tubes were subcultured onto Sabouraud plates and incubated overnight. Count the forming colonies.

Statistical analysis: Each experiments were carried out in triplicate. The data were statistically analysed using software SPSS 11.5. A least significant difference (LDS 0.05) was used to test effect of essential oil through a general linear model. The test was statistically significant at $\mathrm{p}<0.05$

\section{RESULTS AND DISCUSSION}

\section{Chemical composition of obtained turmeric oil}

Percentage yield of $C$. longa rhizome hydrodistillation was $0.93 \%$. The essentiol oil was analysed by GC-MS system and the components are given in fig 1 . The identity of the components was assigned by comparing their GC retention time and the mass spectra with those of authentic reference compounds in mass spectra library Nist 98.1 and Wiley 275.L ( $\geq 90 \%$ ). By this method, 13 compounds were identified in the obtained oil.
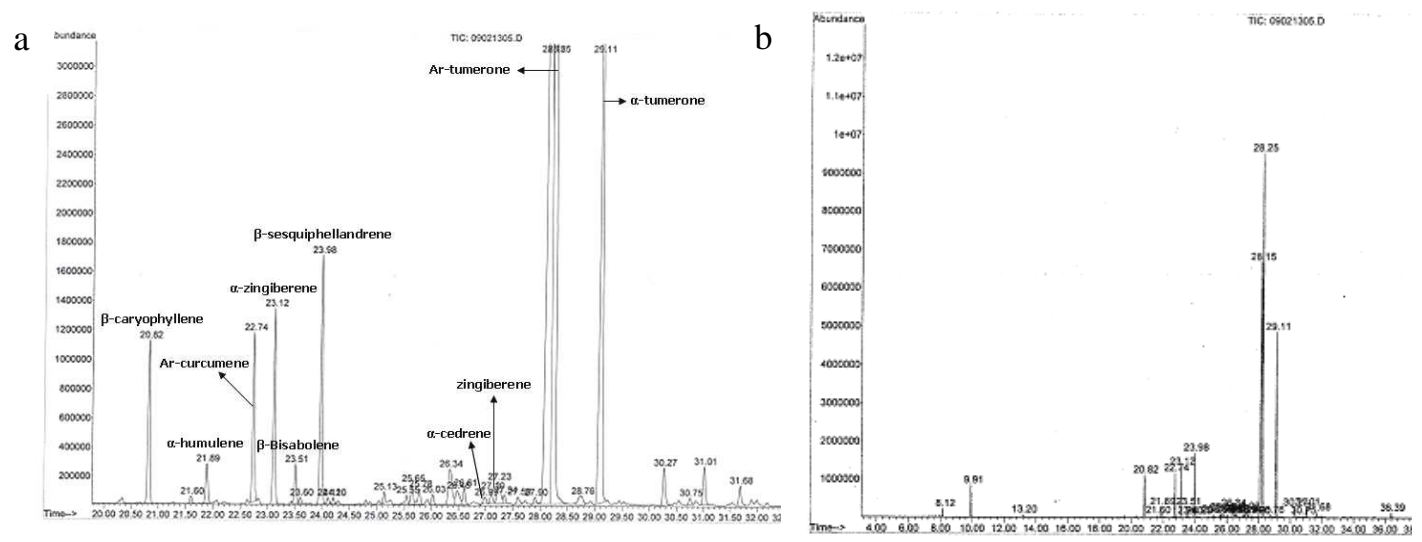

Fig. 1. Volatile compounds of turmeric oil obtained by hydrodistillation (a) and monoterpenes (b).

The major peaks were turmerones (arturmerone and $\alpha$-turmerone) composed more than $44 \%$, followed by other sesquiterpenes such as $\beta$-sesquiphellandrene, $\alpha$-zingberene and $\beta$-caryophyllene (more than $10 \%$ ). In this oil, two monoterpenes were identified, 1,8-cineole and $\alpha$-terpinolene at the rentention times 8.13 and 9.91, respectively (fig. $1 \mathrm{~b}$ ). There are $37 \%$ 
of unidentified compounds in Vietnamese turmeric oil.

\section{Antifungal activity in vitro}

By disc diffusion method on Sabouraud's dextrose agar, the presence of inhibition zone and zone diameter were evaluated for assessment of antifungal activity of turmeric oil.
Sterile $6 \mathrm{~mm}$ diameter filter paper discs were impregnated with the oil diluted by ethylene glycol to desired concentration. Negative control were prepared using the same solvent. Experimental discs were incubated at $30^{\circ} \mathrm{C}$ overnight for $C$. albicans and 36 hours for T. mentagrophyte (table 1).

Table 1. Antifungal activity of Vietnames turmeric oil ${ }^{*}$

\begin{tabular}{|l|c|c|c|c|c|}
\hline \multirow{2}{*}{\multicolumn{1}{|c|}{ Fungi }} & \multicolumn{5}{c|}{ Concentration of turmeric oil (\%) } \\
\cline { 2 - 6 } & 0.3 & 0.5 & 0.7 & 1.0 & 2.0 \\
\hline Candida albicans & $0.3 \pm 0.4$ & $1.6 \pm 0.3$ & $1.7 \pm 0.5$ & $1.8 \pm 0.3$ & $2.6 \pm 0.7$ \\
\hline Trychophytol mentargrohytes & $0.2 \pm 0.1$ & $0.9 \pm 0.2$ & $1.4 \pm 0.2$ & $1.6 \pm 0.2$ & $2.2 \pm 0.1$ \\
\hline
\end{tabular}

* Inhibition zone $(\mathrm{mm})$. Mean \pm standard deviation where $\mathrm{n}=3$ and data is significant at $\mathrm{p}<0.05$.

There are great number reports concerning antimicrobial activity of turmeric oil $[12,9,10$, $4,15]$. Depending on the oil source, method of extraction and the nature of tested microorganisms, varying degree of inhibition of turmeric oil was observed. MICs of Hexane extract of rhizome turmeric against T. mentagrophytes and T. rubrum varied from $230-919 \mu \mathrm{g} / \mathrm{ml}$, depending on the strains [1]. The MIC of freshly distilled oil from Thailand turmeric against some clinical dermatophyte was $7.8 \mathrm{mg} / \mathrm{ml} \mathrm{[15].} \mathrm{Using} \mathrm{the} \mathrm{whole} \mathrm{plant}$ bioassay, Lee et al. (2003) [7] evaluated the control values of methanol extract of the Curcuma rhizome to six plant disease organisms. This extract exhibited good fungicidal activity against rice sheath blight caused by $R$. solani, late blight caused by
$P$. infestans and barley powdery mildew caused by $E$. graminis. Hydrodistillation turmeric oil in India had MICs against C. albicans, A. niger and Staphylococcus aureus at 5.5, 6.7 and 1.95 $\mu \mathrm{g} / \mathrm{ml}$, respectively [13]. From table 1, it was obviously that MIC of oil from Vietnamese turmeric against investigated fungi was $0.5 \%$. T. mentagrophytes strains seems to be more resistant to the turmeric oil than $C$. albicans.

\section{Determination of minimum killing time}

The forming colonies on Sabouraud agar were determined after defined intervals of time of fungal incubation in the turmeric oil (table 2; fig. 2, 3). The results showed that $C$. albicans was killed after 1 hour incubation in turmeric oil, and T. mentagrophytes was more resistant toward oil. This strain was killed only after 90 min incubation in the oil.

Table 2. Surviving numbers of fungi after incubation in turmeric oil

\begin{tabular}{|c|c|c|}
\hline Time $(\mathrm{min})$ & C. albicans $(\mathrm{CFU} / \mathrm{ml})$ & T. mentagrophytes $(\mathrm{CFU} / \mathrm{ml})$ \\
\hline 0 & $8.6 \times 10^{3}$ & $7.5 \times 10^{3}$ \\
\hline 15 & $2.1 \times 10^{3}$ & $3.0 \times 10^{3}$ \\
\hline 25 & $1.5 \times 10^{3}$ & $1.9 \times 10^{3}$ \\
\hline 45 & $1.2 \times 10^{2}$ & $6.0 \times 10^{2}$ \\
\hline 60 & 0 & $4.0 \times 10^{2}$ \\
\hline 90 & 0 & 0 \\
\hline
\end{tabular}

Experimental examination for biological properties and use of medicinal plants in vitro and in vivo has been one of the principal criteria of drug discovery since centries. Although turmeric rhizome powder is popularly used in Vietnam for human ailments, but there was lack of experimental verification. Curcuma oil showed positive activity against fruit spoiling 
fungi (Cladosporium cladosporioides (Fres.) de Vries, Cladosporium tenuisimum Cooke, Aspergillus japonicus Saito, Aspergillus tubingensis Mosserary and Aspergillus versicolor Vuill. Tiraboschi [3]. According to many reports, main component in turmeric oil responsible for antibacterial activity are turmerones, especially ar-turmerone [9, 10, 13]. It is also recognised that synergistic effect of some active components in the oil contributes to antifulgal activity. The varying degree of sensitivity of the microbial organisms toward turmeric oil may due to both the intrinsic tolerance of microorganisms and the nature and combination of compounds present in the essential oil [10]. The mechanism of action of essential oils was reported by some authors and remains somewhat controvesial. Some studies suggest that the compounds may penetrate the microorganisms and react with active sites enzymes and/or interfere with cellular metabolism; most evidence supports direct disruption of cellular membranes and concentration-dependent pro-oxidant cytotoxic effects $[2,16]$. The antifungal activity may due to its ability to disrupt the permeability barrier of the plasma membrane, mitochondrial dysfunction-induced ROS accumulation in fungi [6].

The essential oil of many plants show a broad spectrum of activity against pest insects and plant pathogenic fungi, ranging from insecticidal, antifeedant, repellent, oviposition deterrent, growth regulatory and antivector activities. Keeping this in mind, plant oils can be used as "green pesticides" in developing countries and they ultimately have great impact in integrated pest management programmes due to their safety to non-target organisms and the environment [11].

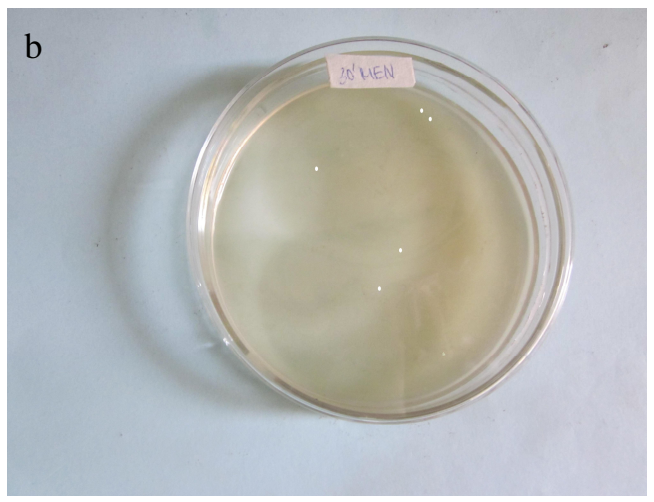

Fig. 2. Candida albicans (a. 0 min; b. $30 \mathrm{~min}$ )
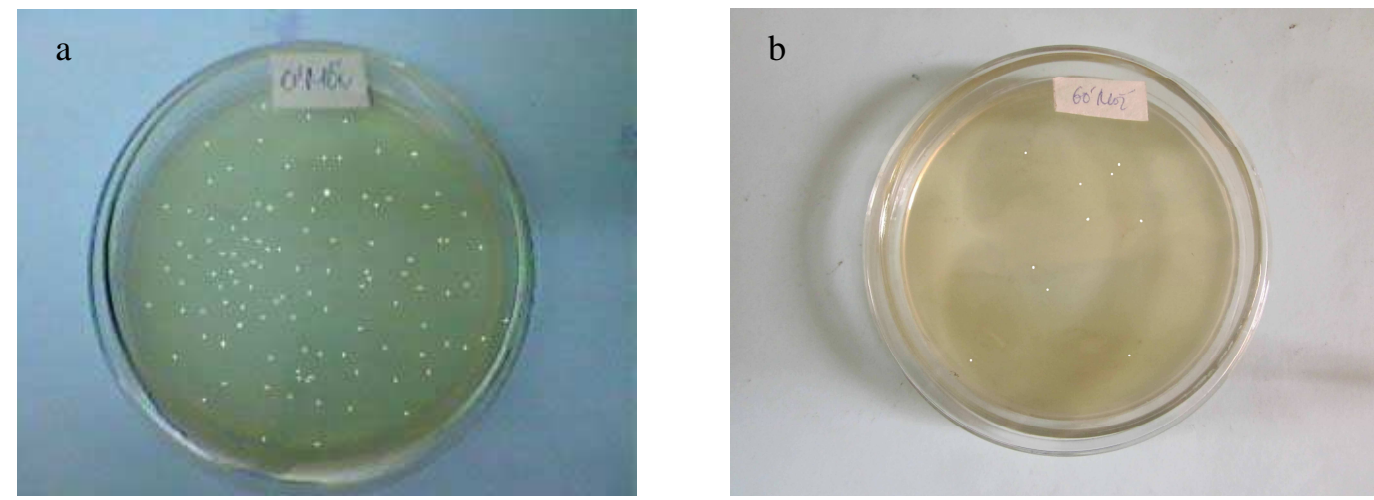

Fig. 3. Trychophytol mentargrohytes (a. $0 \mathrm{~min}$; b. $60 \mathrm{~min}$ ) 


\section{CONCLUSION}

The essential oil from Vietnamese Curcuma longa had high level of turmerones and exihibited not only fungistatic, but also fungicidal effect on dermatophytes $T$. mentagrophyte and $C$. albicans. The obtained results demonstrated the potential use of turmeric oil in treatment of dermatomycosis. The development of natural antifungals will help to decrease the negative effect of synthetic drugs.

\section{REFERENCES}

1. Apisariyakul A., Vanittanakom N., Buddhasukh D., 1995. Antifungal activity of turemeric oil extracted from Curcuma longa (Zingiberaceae). J. Ethnophar., 49: 163-169.

2. Bin J. I., Yassin M. S. M., Chin C. B., Chen L. L., Sim N. L., 2003. Antifungal Activity of the Essential Oils of Nine Zingiberaceae Species. Pharmac. Biology, 41(5): 392-397.

3. Nguyen Thi Kim Cuc, Tran Thi Kim Dung, Pham Viet Cuong, 2010. Antimicrobial effect of turmeric oil (Curcuma longa L.). J. Sci. Tech., 48(5): 37-45. Vietnam.

4. Phan Minh Giang, Van Ngoc Huong, Phan Tong Son, 2000. Antimicrobial activity of sesquiterpene constituents from some Curcuma species of Vietnam. Vietnam $\mathrm{J}$. Chem., 38(1): 91-94.

5. Jain S., Shrivastava S., Nayak S., Sumbhate S., 2007. PHCOG MAG.: Plant Review Recent trends in Curcuma longa Linn. Pharmacognosy Reviews, 1(1): 119-128.

6. Jun T., Ban X., Zeng H., He J., Chen Y., Wang Y., 2012. The Mechanism of Antifungal Action of Essential Oil from Dill (Anethum graveolens L.) on Aspergillus flavus. PLoS ONE, 7(1): e30147.

7. Lee Hoi-Seon, Kyung-Ja Choi, Kwang-Yun Cho, Young-Joon Ahn, 2003. Fungicidal activity of ar-turmerone identified in Curcuma longa rhizome against six phytopathogenic fungi. Agric. Chem. Biotechnol., 46(1): 25-28.
8. Mónica Z., Gonçalves M. J., Cavaleiro C., Canhoto J., Vale-Silva L., Silva M. J., Pinto E., Salgueiro L., 2011. Chemical composition and antifungal activity of the essential oils of Lavandula viridis L'Hér. J. Medical Microbiol., DOI:10.1099/jmm.0.027748-0.

9. Negi P.S., Jayaprakasha G. K., Rao L. J. M., Sakariah K. K., 1999. Antibacterial activity of turmeric oil: a by product from curcumin manufacture. J. Agr. Food Chem., 47: 42974300 .

10. Norajit K., Laohakunjit N., Kerdchoechuen O., 2007. Atibacterial effect of five Zingiberaceae essential oils. Molecule, 12:2047-2060.

11. Opender K., Walia S., Dhaliwal G. S., 2008. Essential Oils as Green Pesticides: Potential and Constraints. Biopestic. Int., 4(1): 63-84.

12. Shagufta N., Jabeen S., Ilyas S., Manzoor F., Aslam F., Ali A., 2010. Antibacterial activity of Curcuma longa varieties against different strains of bacteria. Pak. J. Bot., 42(1): 455-462.

13. Singh S., Sathpathy B.S., Sahoo R.K., Subudhi E., Nayak S., 2011. In vitro validation and phyto-constituents analysis of turmeric extract: an ethnological alternative for eye treatment. Res. J. Medicinal plant, DOI:10.3923/rjmp.2011

14. Wilson B., Abraham G., Manju V. S., Mathew M., Vimala B., Sundaresan S., Nambisan B., 2005. Antimicrobial activity of Curcuma zedoaria and Curcuma malabarica tubers. J. Ethnopharmacol., 99: 147-151.

15. Wuthi-undomlert M., Grisanapan W., Luanratana O., Caichompoo W., 2000. Antifungal activity of Curcuma longa grown in Thailand. Southeast Asian J. Trop. Med. Public Health, 31 Suppl1 (Abstract).

16. Zuzarte M., Gonçalves M. J., Canhoto J., Salgueiro L., 2011. Antidermatophytic activity of essential oils. Science against microbial pathogens: communicating current 
research and technological advances. A. Mendez-Vilas (Ed.), 1167- 1178.

17. Youn C. H., Lee E. H., 2004. Antifungal activity and inhibitory modes of volatile vapours of essential oils. Mycobiology, 32(2): 102-104.

\title{
ĐÁNH GIÁ HOẠT TÍNH KHÁNG NẤM GÂY BỆNH TRÊN DA CỦA DỊCH CHIÊT NGHỆ (Curcuma longa L.) IN VITRO
}

\author{
Nguyễn Thị Mai Hương ${ }^{1}$, Phạm Việt Cường ${ }^{2}$, Nguyễn Thị Kim Cúc ${ }^{2}$ \\ ${ }^{1}$ Trường Đại học Kinh tế kỹ thuật Công nghiệp \\ ${ }^{2}$ Viện Hóa sinh biển, Viện Hàn lâm KH \& CN Việt Nam
}

\section{TÓM TÁT}

Curcuma longa L. là loại cây thuốc thân rễ lâu năm, tinh dầu của nó được xác định có hiệu quả kháng nấm, kháng khuẩn, chống oxy hóa, chống độc và chống khối u. Hoạt tính kháng nấm hại da của tinh dầu nghệ đã được chứng minh. Nghiên cứu này được tiến hành nhằm đánh giá hoạt tính ức chế của tinh dầu từ cây nghệ vàng của Việt Nam đối với 2 loại nấm hại da là Trychophytol mentargrohytes và Candida albicans. Tinh dầu nghệ thu được bằng phương pháp cất lôi cuốn hơi nước và thành phần hóa học của tinh dầu được xác định bằng GC/MS. Bằng cách so sánh với các hợp chất chuẩn trong thư viện khối phổ Nist 98.1 và Wiley 275.L, có 13 hợp chất đã được nhận dạng trong tinh dầu từ nghệ vàng Việt Nam. Kết quả nhận được cho thấy tinh dầu rất giàu thành phần turmerones (khoảng 44\%), hợp chất được công nhận là phần tử chủ yếu cho hoạt tính kháng vi sinh vật.

Bằng phương pháp khuếch tán trên đĩa thạch, hoạt tính kháng nấm của tinh dầu nghệ đối với T. mentargrophyte and $C$. albicans đã được chứng minh. Nồng độ ức chế tối thiểu cho T. mentargrophyte và C. albicans là $0,5 \%$. Thời gian tối thiểu để diệt $C$. albicans là 60 phút và đối với $T$. mentargrophyte là 90 phút ủ trong tinh dầu.

Tù khóa: Curcuma longa, dermatophytes, tinh dầu nghệ, turmerones, ức chế.

Ngày nhận bài: 10-4-2012 